\title{
Consequencialismo Jurídico, Racionalidade Decisória e Malandragem
}

\author{
Luis Fernando Schuartz'
}

\begin{abstract}
"The concept of unintended consequences originally introduced uncertainty and open-endedness into social thought, but in an escape from their new freedom the purveyors of the perverse effect retreat to viewing the social universe as once again wholly predictable" (A. Hirschman, The Rhetoric of Reaction)
\end{abstract}

O objetivo do presente artigo é apresentar e discutir algumas características e implicações do consequencialismo jurídico. A discussão se ocupa, primariamente, com a identificação das condições de adequação (racionalidade) de decisões judicantes orientadas, ou que deveriam orientar-se - de acordo com participantes ou observadores da situação de decisão - em consequências, e com a investigação dos efeitos resultantes do confronto entre as referidas condiçōes e as restrições informacionais que, tipicamente, afetam os processos decisórios de aplicação do direito por autoridades judicantes. $O$ artigo também propōe uma classificaçāo preliminar e um mapeamento conceitual exploratório para servirem de ponto de partida e referência para futuras reflexões (inclusive, de natureza normativa) acerca do fenômeno do consequencialismo jurídico, e para eventuais pesquisas empíricas sobre a sua recepção no Brasil.

\section{O consequencialismo jurídico e as suas consequências}

No âmbito deste artigo, a expressão consequencialismo jurídico será utilizada em um sentido extremamente amplo, i. e., como qualquer programa teórico que se

1 Professor da FGV/Rio de Janeiro. 
proponha a condicionar, ou qualquer atitude que condicione explícita ou implicitamente a adequação jurídica de uma determinada decisão judicante à valoração das consequências associadas à mesma e às suas alternativas. Nesses termos, denominarse-á de "consequencialista" não apenas a posição segundo a qual uma decisão $D$ é correta se e somente se não se encontra, com relação a ela, alguma decisão alternativa a que se associem consequências preferíveis àquelas associadas a $D$. Esse tipo de consequencialismo, que será denominado de "forte", é somente um dos extremos de um conjunto de tipos ordenado de acordo com a prioridade atribuída à valoração de consequências no juízo de adequação de uma determinada decisão judicante, ou, alternativamente, com a exclusividade atribuída a essa forma de valoração na formulação desse juízo.

Assim, será tratada como consequencialista tanto a posição que reserva à valoração das consequências da decisão um papel residual no referido juízo de adequação (quando, e. g., entender-se que a consideração das consequências somente deva entrar em cena se as técnicas jurídicas convencionais supostamente não forem capazes de reduzir o conjunto das decisões juridicamente adequadas a um único elemento, i. e., a uma única decisão correta), quanto aquela que admite, ao lado da análise consequencialista e com um peso maior ou menor no processo decisório, formas diferentes de argumentação (e.g., a que se ocupa em medir a "distância" da decisāo ou de suas premissas daquilo que supostamente seria exigido pela interpretação gramatical de um dispositivo legal ou de um precedente paradigmático). A concepção particular que se propōe a defender as valorações de consequências enquanto elementos constitutivos da fundamentação de decisões judicantes, que devem no entanto ser inseridas e contempladas no âmbito dos processos decisórios com peso no máximo igual ao peso conferido a argumentos nāo consequencialistas, caracterizará então o tipo "fraco" de consequencialismo jurídico.

O valor heurístico de uma compreensão mais ampliada do significado da expressão "consequencialismo jurídico" está na possibilidade de releitura de um universo - ao que me parece - bastante significativo de opiniōes de juristas e decisões de juízes como expressões de posições consequencialistas diferenciadas e, não obstante, de submissão desse universo de opiniōes e decisões a um conjunto comum de condições universais de racionalidade. Em particular, ao selecionar ou pretender fundamentar uma certa decisão a partir da análise das consequências produzidas por ela e pelas suas alternativas, o decisor abre um flanco para requerimentos de prestação de contas cujo atendimento estará sujeito a critérios científicos (extrajurídicos) de adequação. Isto porque qualquer juízo consequencialista contém uma dimensão descritiva, na qual deverá ser positivamente especificada, para cada alternativa de decisāo disponível, a sua respectiva consequência; e tal especificação (e possivelmente, por extensão, também a decisão que nela se baseia) será objetivamente inadequada se puder ser mostrado que as consequências associadas às decisões em questão são diversas daquelas imaginadas pelo decisor. Em qualquer hipótese, é do decisor o dever argumentativo no sentido da validação erga omnes dos juízos de fato que relacionam causalmente decisões e consequências. 
$\mathrm{O}$ alcance universal da pretensão de validade que necessariamente acompanha todo juízo consequencialista restringe-se, no entanto, à sua dimensão descritiva. ${ }^{2}$ Da componente normativa do juízo, consistente na ordenaf̧ão do conjunto de consequências de acordo com critérios valorativos, poder-se-á cobrar, no máximo, a consistência interna desses critérios e, dependendo das circunstâncias, a sua compatibilização externa com normas e práticas aceitas como devidas pelos integrantes de uma comunidade jurídica particular. $\mathrm{O}$ espaço social para a resolução ou acomodação posterior das divergências, nesse caso, nāo é mais a ciência, mas a política. Por exemplo, sejam $D_{1}$ e $D_{2}$ duas alternativas de decisão que geram, respectivamente, as alocações econômicas $C_{1}$ e $C_{2}$, e suponha-se que $C_{1}$ seja mais eficiente que $C_{2}$ e $C_{2}$ seja mais justa do ponto de vista distributivo que $C_{1}$ (para uma dada definição de justiça distributiva). Neste caso, uma eventual opção do decisor por $D_{2}$ somente será irracional erga omnes se, segundo as normas e práticas consideradas como obrigatórias na comunidade jurídica de que é parte o decisor, ou, ainda, segundo as normas tratadas como obrigatórias pelo decisor, o valor que deveria ter orientado a sua decisão for a eficiência e não a justiça distributiva - caso em que quaisquer divergências relativas à adequação de $D_{2}$ serão solucionáveis por meio de argumentos econômicos (assumindo-se que todos os dados e informaçōes necessários a um desfecho conclusivo da discussão estarão disponíveis aos participantes da discussão). ${ }^{3}$

Evidentemente, as divergências relativas a valores também podem ser discutidas de maneira racional, com algum dos participantes sendo racionalmente convencido a adotar as preferências expressadas por outros. Mas a possibilidade de sucesso no convencimento dos demais não significa que ao menos um dos participantes esteja equivocado na presença de opiniões divergentes. Dentro de limites bastante largos, dissensos quanto a valores não são tratados normativamente

2 Essa afirmação não deve ser entendida como implicando a adoção de uma posição filosófica de "relativismo moral". O ponto é que os valores aos quais se refere a dimensão normativa dos juízos consequencialistas estão localizados quase sempre em um espaço no qual convivem, de forma nãohierarquizada, diversas preferências "ético-políticas" (sobre a diferença entre juízos éticos e morais, ver Habermas, "Vom pragmatischen, ethischen und moralischen Gebrauch der praktischen Vernunft", em Erläuterungen zur Diskursethik, Suhrkamp, 1991, p. 100-118; sobre o significado das questōes éticopolíticas e a sua diferença em relação às questões morais, ver, do mesmo autor, Faktizität und Geltung, Suhrkamp, 1992: questōes ético-politicas devem ser respondidas da perspectiva dos membros de uma comunidade político-jurídica particular, que deve deliberar coletivamente acerca das suas preferências. Em um nivel ainda mais particularizado, a saber, dos diferentes grupos sociais que compöem as comunidades jurídico-políticas na sociedade moderna, o pluralismo de valores deixou de ser um problema normativo com a erosão das bases culturais que sustentavam a suposição da irracionalidade dos dissensos. Nas discussōes morais, o que se testa argumentativamente é a pretensão das propostas normativas a um assentimento universal).

3 O exemplo não pressupōe uma tomada de posição quanto à consistência teórica de afirmaçōes da prioridade do valor da eficiência econômica sobre o da justiça distributiva enquanto orientação normativa nos processos de criação ou aplicação de normas jurídicas (ver a respeito Shavell, "A Note on Efficiency vs. Distributional Equity in Legal Rulemaking: Should Distributional Equity Matter Given Optimal Income Taxation?", The American Economic Review, v. 71, no 2, 1981, p. 414-418: “despite imperfect ability to redistribute income through taxation, everyone would strictly prefer that legal rules be chosen only on the basis of their efficiency"). 
como problemáticos. Pelo contrário, eles são vistos cada vez mais frequentemente como dados estruturalmente inseparáveis dos processos de formação da vontade política e produção das normas do direito positivo na sociedade moderna. Como resultado desse movimento histórico de evolução sociocultural, as críticas incidentes sobre as valoraçōes inerentes aos juízos consequencialistas têm o seu alcance determinado por critérios de adequação indexados às preferências éticas do autor da crítica, e o seu sucesso condicionado à existência de intersecção não vazia entre tais preferências e as do auditório ou do responsável pela decisão criticada.

Em suma, juízos consequencialistas exibem uma estrutura dual, com cada elemento que os compõe (i. e., o descritivo e o normativo) estando sujeito a diferentes condiçōes de racionalidade que, em conjunto, definem os critérios de adequação do juízo como um todo. A explicitação dessa estrutura e das condições de racionalidade que incidem sobre os seus componentes é um importante passo preparatório para diferenciaçōes conceituais relevantes e pesquisas empíricas realmente informativas acerca de padrōes de decisão mais recorrentes no âmbito do Poder Judiciário brasileiro. Algumas dessas pesquisas, apesar de louváveis pelo pioneirismo, pela criatividade ante a escassez dos dados e pela coragem no combate às reaçōes hostis e preconceituosas, pecam por imprecisões conceituais e por uma insuficiente complexidade teórica que lhes retira boa parte dos méritos acadêmicos. Isso ocorre mesmo quando as pesquisas são orientadas por conjecturas que apontam em direções produtivas, como se verifica, tipicamente, com as hipóteses acerca da existência de vieses nas decisōes judiciais. Escritos quase sempre em um estilo bastante assertivo e categórico, mesclando de maneira mais ou menos explícita e consciente argumentos teóricos ou empíricos e político-normativos, esses trabalhos normalmente convergem para a crítica de uma atitude "social-consequencialista" que acreditam poder identificar, sistematicamente, nas decisōes judiciais - os exemplos mais comuns provêm de casos relacionados ao inadimplemento de contratos privados envolvendo devedores pobres e credores ricos -, vale dizer, da suposta atitude de favorecimento sistemático da parte economicamente mais fraca em nome da realização de alguma concepção de justiça social. Não necessariamente viesada por interesses parciais ou ideológicos, a crítica é dirigida ora a decisōes específicas, ora ao Poder Judiciário enquanto instituição, e a sua manifestação mais corrosiva assume a forma de uma crítica interna: a do argumento dos "efeitos perversos".

$\mathrm{O}$ argumento em questão usa uma tática condicionalmente consequencialista. A sua graça consiste em assumir, "para fins de argumentação", a ordem de preferências daquele contra quem o argumento se dirige, e mostrar que a decisão por este escolhida, em vez de promover a realização do estado de coisas desejado, resulta no seu oposto. Há, de fato, algo de perverso nessa conspiração da realidade para a produção de consequências contrárias às pretendidas, normalmente na melhor das intenções, com a decisão tomada. Contudo, isso não impede o efeito destrutivo do argumento que antecipa o trágico destino; pelo contrário, apenas o torna mais dramático. Os exemplos são abundantes. Pretende-se garantir me- 
lhores condições habitacionais para locatários mais vulneráveis com uma decisão que reconhece a existência de uma "garantia implícita" nos contratos de locação? Ora, esse reconhecimento levará a um aumento nos preços dos aluguéis e uma redução da oferta de imóveis para fins de locação, afetando de maneira negativa justamente a situação dos indivíduos mais pobres, que, anteriormente à decisão, estavam dispostos a alugar os imóveis disponíveis em piores condições, em razão do menor preço. Isto posto, quem, em sã consciência, poderá defender a decisão? $\mathrm{O}$ argumento é facilmente generalizável: a mesma lógica valeria para quaisquer outras decisōes que visassem melhorar a situação de uma determinada classe de pessoas por meio de intervenções de natureza redistributiva em contratos nos quais figurem, efetiva ou potencialmente, como partes.

A identificação do equilíbrio nestes casos é na verdade bem mais complexa do que supōe esta narrativa, como atesta a rica discussão acadêmica que se seguiu às decisōes dos tribunais americanos reconhecendo a "implicit warranty of habitability" nos contratos de locação, e à adoção de housing codes em vários Estados da federação. ${ }^{4} \mathrm{Um}$ dos principais complicadores está na necessidade de determinar o comportamento das curvas de oferta $e$ demanda após a mudança nas regras do jogo implicada pela decisão (pois o novo equilíbrio resultará da interação entre ambas), mais precisamente, na possibilidade, não descartável a priori, de que as duas curvas sejam e se desloquem de forma tal que não se verifique, com a mudança, redução da quantidade demandada e ofertada (ainda que possa haver aumento do preço de equilíbrio), ineficiência alocativa ("perda de peso morto") e redução do excedente do consumidor. Apesar dessa e de outras complicações (e. g., a escolha, pelo decisor, de um objetivo a realizar que contemplasse redistribuições de renda no interior do conjunto dos consumidores ou, o que seria a meu ver mais apropriado de um ponto de vista normativo, a modelagem da situação investigada como um problema de decisão com múltiplos atributos, possivelmente incomensuráveis entre si, i. e., não obrigatoriamente redutíveis a uma mesma unidade), o argumento dos efeitos perversos permanece coerente em abstrato, mas tem reduzido o seu campo de aplicação em decorrência do acréscimo nos pressupostos para um uso empiricamente responsável.

Os precisos limites desse campo, porém, não costumam ser perfeitamente visíveis no momento da tomada da decisão. Pelo contrário, é bastante inverossímil que a situação deixe-se descrever adequadamente como um problema de decisão sob condições de certeza, em que alternativas de decisão associam-se a consequências deterministicamente, ou mesmo, por modelos que incorporem o elemento de incerteza na forma de distribuiçōes objetivas de probabilidade, como se as consequências em questão fossem estruturalmente equiparáveis a eventos

\footnotetext{
4 Para uma análise mais geral, cf. Craswell, Passing on the Costs of Legal Rules: Efficiency and Distribution in Buyer-Seller Relationships, Stanford Law Review, v. 43, nํ 2, 1991, p. 361-398. Para a discussão dos efeitos distributivos associados aos housing codes, ver a extensa bibliografia mencionada na nota de rodapé 1 do referido artigo.
} 
cujas frequências relativas mantêm-se estáveis se os experimentos aleatórios que os produzem são repetidos um número suficientemente elevado de vezes. Decisōes judiciais orientadas nas próprias consequências são, tipicamente, decisões sob incerteza subjetiva e, nesse terreno, é difícil que possam mover-se, para usar uma expressão de Niklas Luhmann, para além da condição de exercícios de imaginação com força jurídica. Independentemente do formato, tanto nos mais canônicos ( $e$. g., na linha de Savage ou de Anscombe-Aumann), como nos mais heterodoxos, ${ }^{5}$ as teorias científicas que se ocupam dos problemas de decisão desta natureza são guias pouco confiáveis para o auxílio de juízes e tribunais na formulação dos prognósticos que deveriam ser capazes de justificar intersubjetivamente para assegurar racionalidade instrumental a suas decisões. O problema não está na consistência e robustez das teorias ou do arsenal de conceitos que as acompanha nas proposiçōes mais substantivas das análises econômicas do direito, mas no acesso às informaçōes necessárias para garantir às decisões a satisfação das condições de adequação que lhe são impostas por tais teorias e conceitos. Sem as referidas informações, reduz-se para ambos o atrito com a realidade, até o ponto em que sua invocaçāo como premissa em uma inferência jurídica torna-se estéril e decorativa, e a conclusão que nela se apoia, o exercício de imaginação com força de direito a que se fez menção acima.

A situação é diferente quando o propósito da crítica é puramente negativo, ou seja, quando busca somente a corrosão do argumento consequencialista invocado para suportar a decisão criticada - e não a proposta, explícita ou implícita, de alguma decisão alternativa que seria superior do ponto de vista de suas consequências -, como costuma ocorrer com as estratégias sustentadas na ideia de um dever de prova nāo satisfeito. Neste caso, não se está diante de uma crítica rigorosamente consequencialista, pois ela se esgota na fundamentação de um voto de desconfiança com relação à capacidade do decisor de prestar contas acerca das razões que justificam a parte consequencialista da decisão. $O$ argumento então assume ares de uma crítica epistemológica, que coloca sob suspeição o conhecimento possível do decisor sobre elementos do problema que seriam necessários a um juízo consequencialista metodologicamente correto. O resultado é análogo se a crítica, apesar de substantiva, não avança no sentido da comparação das decisōes em função de suas consequências esperadas, satisfazendo-se com a problematização da asserção ou pressuposição, pelo decisor, do nexo de causalidade entre a decisão escolhida e suas consequências. Em ambos os casos, a crítica solapa os fundamentos da decisão sem recomendar uma outra em seu lugar em virtude dos seus efeitos esperados.

\footnotetext{
5 Para uma apresentação das principais teorias e modelos formais que dizem respeito ao problema da decisão racional, cf. Kreps, Notes on the Theory of Choice, Westview, 1988. Uma excelente introdução a esse assunto ainda pode ser encontrada no livro clássico de Luce e Raiffa, Games and Decisions, Dover, 1957. Desde a sua formulaçāo, as teorias canônicas têm sido acompanhadas de críticas mais ou menos radicais, que resultam seja em propostas adaptativas ou de acomodaçōes progressivas da teoria original (como, por exemplo, no trabalho pioneiro de Kahnemann e Tversky e na literatura subsequente sobre "heurísticas e vieses"), seja em propostas de ruptura - inclusive, de natureza normativa - com os seus pressupostos (como, paradigmaticamente e por exemplo, ocorre com Herbert Simon e na literatura por este inaugurada acerca das implicações do conceito de "racionalidade limitada").
} 
Enunciados categóricos sobre "limites cognitivos" devem ser recebidos ceticamente, e não vejo razão para que algo do gênero mereça um tratamento mais favorável no presente caso. Contudo, em um ambiente institucional caracterizado por enorme escassez de pessoal tecnicamente treinado, informações pertinentes e bancos de dados prontamente disponiveis; por significativas assimetrias de recursos para fins de litigância e amplos espaços para o uso estratégico de informações privadas e de direitos processuais; e, enfim, por uma agenda de trabalho que coloca sérias restrições materiais e temporais aos esforços de solução de casos mais complexos pelos julgadores, não há como afastar a hipótese de que seriam - ao menos no Brasil - de natureza estrutural os obstáculos à submissão dos processos reais de decisão no âmbito do Poder Judiciário aos mesmos padrões de racionalidade a partir dos quais são avaliadas as demais tentativas de intervenção social numa sociedade moderna. Quando essa hipótese se torna suficientemente plausível e a realidade parece desviar-se sistematicamente da norma até então usada para avaliá-la, pode ter chegado o momento de afrouxar a norma ou de simplesmente substituí-la. O problema é justamente determinar esse momento - um problema cuja solução, em face da decisão a tomar, estará, em regra, obstruída tanto para o decisor como para quem lhe observa.

Exemplos particularmente ilustrativos deste fato podem ser achados em atos cujo - no vocabulário kelseniano - "sentido subjetivo" fosse a instituição de uma norma jurídica que estabelecesse o dever para o Estado de garantia, para a totalidade dos seus cidadãos, de condições materiais mínimas para a fruição de liberdades públicas e privadas formalmente reconhecidas, bem como em atos cujo "sentido subjetivo" fosse a imposição, ao Estado, do cumprimento do referido dever geral em um caso concreto a fim de viabilizar a realização daquela finalidade. Como avaliar a racionalidade desses atos? Em ambos os casos, está-se diante de atos intencionalmente direcionados à realização de um estado de coisas desejado. Enquanto tais, eles deveriam sujeitar-se aos rigorosos critérios de adequação normalmente empregados no julgamento das nossas tentativas de intervenção sobre o mundo (natural ou social) e à jurisdição do único tribunal competente para pronunciar-se, em última instância, acerca da componente propriamente positiva (não normativa) do juízo: a ciência moderna. Ocorre que o veredicto final da ciência poderá construir-se sobre um processo de produção e teste de hipóteses que estava, quase certamente, indisponivel àquele que tomou a decisão, quando a tomou. Eventualmente, alguém constatará no futuro que a decisão tomada não era adequada à realização do fim que buscava realizar, ou mesmo, que estaria fadada a resultar no seu contrário. Porém, é questionável o valor dessa constatação ex post do ponto de vista da definição - e do controle da sua satisfação - dos critérios de racionalidade aplicáveis ex ante na análise dos atos em questão. Paradoxalmente, quanto mais sofisticado e complexo vai ficando o conhecimento científico que orienta a avaliação ex post, mais problemática se torna a sua aptidão para servir de metro na avaliação ex ante da racionalidade instrumental dos atos avaliados. Salvo em casos de irracionalidade aparente, o juízo acerca da adequação entre decisões e 
objetivos e, com ele, o exercício da crítica consequencialista das primeiras devem ser relaxados. ${ }^{6}$

Essa conclusão nāo implica que algum tipo de coerência entre as premissas teóricas e empíricas inseridas (explícita ou implicitamente) nas inferências jurídicas, de um lado, e as proposições do mainstream acadêmico aplicável, de outro lado, não figure de fato entre as condiçōes de racionalidade jurídica dessas inferências, ou seja, que os juízes e tribunais não se tratem reciprocamente como racionalmente obrigados a conceder à ciência alguma prioridade na determinação da verdade $\mathrm{e}$ falsidade dessas premissas (ou de um subconjunto das mesmas) no interior do sistema jurídico. Não se está afirmando, logo, que na sociedade moderna não toque à ciência algum poder definidor com relação ao conjunto das decisōes juridicamente corretas nos casos concretos ou ao que seria juridicamente correto e incorreto decidir, assim como não se está dizendo que decisōes flagrantemente incorretas do ponto de vista científico não possam ser tomadas, não transitem em julgado e não sejam aplicadas pelo aparato repressivo da polícia. $O$ ponto é que a plausibilidade, segundo a ciência, das referidas premissas não é, em geral, condição necessária seja da sua plausibilidade segundo o direito, seja da correção juridica das decisões que sobre elas se apoiam. ${ }^{7}$ A plausibilidade científica da proposição que afirma a propriedade $P$ a respeito do evento $E$ tampouco é, em geral, condição suficiente para a adequação jurídica da decisão que pressupõe, do decisor, a tomada de posição acerca da relação entre $P$ e $E$ (mesmo assumindo-se que todas as demais premissas sobre as quais a decisão se sustente são válidas). O conhecimento científico é, em regra, insuficientemente seletivo para isolar, como plausível, apenas uma única proposição para cada premissa teórica ou empírica requerida na inferência que conduzirá à decisão. Na maior parte das vezes, pode-se fabricar, para cada evento controvertido a respeito do qual a motivação da decisão deva pronunciar-se, proposiçōes que são mutuamente excludentes e cientificamente plausíveis.

A atitude de relaxamento da racionalidade instrumental é diferente das atitudes de reafirmação, neutralidade ou rejeição diante do consequencialismo jurídico, inspiradas em uma ou outra variante do que se poderia denominar "consequencialismo truncado". Na sua versão mais alinhada com a maneira usual de se argumentar e decidir no âmbito do direito, assiste-se a uma ruptura com o paradigma canônico em teoria da decisão, que se faz a partir da exploração do conceito de "racionalidade limitada" (bounded rationality). ${ }^{8} \mathrm{~A}$ diferença essencial entre os modelos de racionalidade limitada e os modelos afinados com a teoria canônica

\footnotetext{
6 Para a análise detalhada desse problema no contexto de uma crítica da teoria da sociedade de Habermas, ver Schuartz, Die Hoffnung auf radikale Demokratie. Fragen an die Theorie des kommunikativen Handelns, Peter Lang, 2001, Caps. IV e VI.

7 Entendendo-se como "corretas" as decisões que, de acordo com os critérios de correção vigentes, merę̧am o tratamento, não as que simplesmente sejam de fato tratadas como corretas por aqueles que deveriam avaliá-las normativamente.

8 A ideia original é de Herbert Simon. Cf. A Behavioral Model Of Rational Choice, The Quarterly Journal of Economics, 69. 1, 1955, p. 99-118.
} 
está na rejeição explícita do postulado de que não há racionalidade decisória sem otimização ou maximização de uma função-objetivo. Aparentemente, a diferença remonta a divergências filosóficas - e antropológicas - a respeito do que deveria ser o conhecimento científico e dos limites e natureza dos aparatos cognitivo e motivacional de organismos da espécie humana, mas é desnecessário chegar tão longe para se convencer da radicalidade da oposição. Para isto, basta, por exemplo, ter em mente que o que é ideal de racionalidade de acordo com o paradigma canônico e suas variações, a saber, o comportamento maximizador e a busca da decisão ótima, transforma-se, sob certas condiçōes, em erro e irracionalidade para a visão rival: com a valorização de padrões de decisão e comportamento supostamente irracionais no modelo canônico, caminha simultaneamente a completa inversão de papéis no plano normativo. ${ }^{9}$

Para a visão rival, a tomada de uma decisão deve ser entendida, nas situações mais interessantes pelo menos, como um processo ativo e criativo de busca orientado por "niveis de aspiração" (aspiration levels). Nesse processo, as alternativas de decisão não são dadas ao indivíduo que deve decidir, mas têm que ser, uma após a outra, descobertas e às vezes produzidas. Em situações mais simples, o processo de busca de alternativas de decisão se estende até que seja encontrada uma alternativa "satisfatória" - no sentido do alcance ou da superaçāo de um certo nível de aspiração associado aos objetivos e interesses do indivíduo. Entretanto, esses níveis de aspiração não permanecem necessariamente como pontos fixos. Em alguns casos, eles devem se ajustar dinamicamente à situação de decisão, elevando-se quando as alternativas satisfatórias forem relativamente fáceis de identificar, e reduzindo-se na hipótese contrária. ${ }^{10} \mathrm{O}$ ponto importante é que a racionalidade desses processos dispensa preocupações com a identificação e escolha da alternativa ótima. Dessa forma, os modelos de racionalidade limitada distinguem-se dos modelos de otimização com restrições. Nestes, os custos asscciados a decisões racionais também são levados em conta, mas no lugar da comparação entre valores assumidos pela variável de escolha e níveis de aspiração, aparece, como vimos, a ideia de uma "regra ótima de parada", ou seja, um critério que determina a interrupção do processo de busca quando os custos e os benefícios marginais associados à busca são iguais. A objeção imediata a essa proposta de solução do problema das limitações de indivíduos de carne e osso em situações reais de decisão é que ela apenas o desloca para um outro nível, uma vez que as condições necessárias para a realização dessa análise custo-benefício demandam uma metarregra ótima de parada, e assim potencialmente ad

\footnotetext{
9 Em Simon, esta valorização é resultado de uma reinterpretação funcionalista dos resultados de observações empíricas (cf. Simon, Rationality as Process and as Product of Thought, em Bell, Raiffa e Tversky (Ed.). Decision making. Descriptive, normative and prescriptive interactions, Cambridge, 1988, p. 58-77). Porém, a força e o apelo do conceito de racionalidade limitada sāo completamente independentes de argumentos desta natureza.

10 Selten, What is bounded rationality?, em Gigerenzer e Selten (Ed.). Bounded Rationality: the Adaptive Toolbox, MIT, 2002, p. 13-36.
} 
infinitum. Os modelos de racionalidade limitada, por sua vez, propõe-se a enfrentar a questão teórica dos critérios de racionalidade de decisōes unindo análises de heurísticas e regras de parada que não envolvem otimização, com análises das estruturas do ambiente que condicionam e determinam o sucesso e o insucesso dessas heurísticas e regras na solução de problemas de decisão específicos. Esta combinação explica por que, em ambientes marcados por elevada complexidade e/ou dinamismo, mecanismos convencionais, rotinas frugais e regras simples de adaptação podem produzir, do ponto de vista do decisor, melhores resultados do que os procedimentos e estratégias mais sofisticados de decisāo recomendados convencionalmente pela teoria canônica. ${ }^{11}$

A representação de um problema de decisão como busca por opçōes orientada em níveis de aspiração e resultados apenas satisfatórios segundo esses níveis é particularmente atraente para se pensar sobre os procedimentos jurídicos de coleta e ponderação de indícios e provas, pois trata-se, por definição, de processos de busca de novas informaçōes sujeitos a restrições cognitivas, que devem ser necessariamente interrompidos em um determinado momento para possibilitar a tomada de uma decisão vinculante em relação a terceiros, e nos quais o recurso ao critério da igualdade entre custos e benefícios marginais enquanto regra de parada parece pouco recomendável por razōes operacionais. Essa conclusão é reforçada com argumentos inspirados na "virada institucional" proposta por alguns autores na teoria da interpretação jurídica, que requer, na escolha da melhor teoria, a reflexão prévia sobre as capacidades institucionais, para a sua aplicação adequada, dos órgãos chamados a aplicá-la nos casos concretos. ${ }^{12}$ No Brasil, onde os recursos públicos destinados para fazer cumprir a legislação são poucos, considerações dessa natureza são inafastáveis. Nessas circunstâncias, não surpreende que teorias que não incorporem, reflexivamente, as suas próprias condições institucionais de aplicação, soem ridiculamente ingênuas ou perigosamente assemelhadas a uma legitimação ideológica.

Mesmo nessa versão truncada e bastante enfraquecida, contudo, a teoria não oferece os meios para a construção de critérios de racionalidade que garantam, simultaneamente, os graus de objetividade, precisāo e realismo na definição de suas condiçōes de satisfação, que seriam necessários para desqualificar os argumentos indicados acima para sugerir à razão instrumental, como regra, uma postura mais relaxada diante de decisões judiciais orientadas em consequências. Com efeito, em primeiro lugar, a diretriz passada pela teoria ao decisor no sentido

\footnotetext{
11 Cf. Gigerenzer e Selten, Rethinking Rationality, obra citada, p. 1-12. Uma posição similar é defendida pelos adeptos da chamada "teoria naturalística da decisão" (ver Lipshitz, Klein, Orasanu e Salas, Taking Stock of Naturalistic Decision Making, Journal of Behavioral Decision Making, 14, 5, 2001. p. 331-352).

12 Cf. Cass Sunstein e Adrian Vermeule, Interpretation and Institutions, Michigan Law Review, 101, 2003, p. 885-951; também, Vermeule, Judging Under Uncertainty: an Institutional Theory of Legal Interpretation, Harvard, 2006; e Schuartz, Quando o Bom é o Melhor Amigo do Ótimo, Revista de Direito Administrativo, 245, 2007, p. 96-127.
} 
de não maximizar e não otimizar, apenas pode justificar-se localmente, i. e., para a decisão particular diante da qual se encontra o decisor. De um ponto de vista global, vale dizer, do conjunto de decisōes do qual a decisão particular é um elemento, a racionalidade da referida diretriz requer um argumento de segunda ordem que mostre que o desempenho da diretriz em termos da realização do objetivo desejado é superior ao de qualquer diretriz alternativa, i. e., que, para o conjunto de decisões, a referida diretriz maximiza a realização do objetivo em questão. ${ }^{13}$ Trata-se, logo, da demonstração de que a renúncia ao máximo ou ótimo local é uma forma de obtenção do máximo global. Não há como prescindir da ideia de maximização sem jogar fora o bebê (a perspectiva normativa) juntamente com a água de banho (uma concepção - de primeira ordem - de racionalidade excessivamente rigorosa). E em segundo lugar, complementarmente, esta demonstraçāo é tão ou mais complexa do que a demonstração que se pretende evitar por meio da diretriz simplificada de primeira ordem, a saber, de que a decisão que se tomou é a que maximizaria a função-objetivo do decisor ou a decisão ótima. Na verdade, é difícil inclusive imaginar um método para testar a afirmação da superioridade da diretriz simplificada sobre as suas rivais. A definição das preferências do decisor por uma ou outra diretriz parecendo ser, afinal, uma questão mais de fé do que de ciência, tem-se o regresso da contenção ex ante do exercício da crítica consequencialista, que aparentava estar superada com a versão supostamente mais frugal da teoria da decisão racional sob condições de incerteza, como a atitude mais recomendável diante de decisōes judiciais que referem-se às próprias consequências para demonstrar a sua correção do ponto de vista jurídico.

\section{Como avaliar as contribuiçōes dos juízes?}

Suponha-se, na linha das observaçōes precedentes, que a atitude adequada diante de decisões judiciais que se orientem nas próprias consequências seja o relaxamento ex ante de juízos normativos acerca da satisfação das condições para a sua racionalidade instrumental. Não seria o caso de se inferir desse fato a necessidade da renúncia, por parte do decisor, a toda e qualquer orientação consequencialista na tomada das suas decisões? De certo modo, e ao contrário das aparências, a invocação, pelo decisor, das consequências (alegadamente desejáveis) da decisão para fins de justificação esteriliza as críticas elaboradas nos mesmos termos. Se no momento inicial, a pretensão intervencionista convida ao dissenso, a falta de uma perspectiva capaz de assegurar racionalmente um consenso ex ante (em retrospectiva, possivelmente) entre as opiniōes em confronto acabará por retirar deste último, no instante seguinte, a força catalisadora que poderia conduzir à produção de novos conhecimentos. É verdade que o efeito de esterilização das eventuais

13 Cf., a respeito deste último ponto, Vermeule, Three Strategies of Interpretation, San Diego Law Review, 42, 2005. 
críticas consequencialistas não significa, necessariamente, uma autoimunização da decisão contra a qual elas se dirigem, pois a discussão poderá também encerrar-se desfavoravelmente àquele que invocou o argumento consequencialista. Porém, ela terá provavelmente sido infrutífera no sentido de reproduzir o faz-de-conta da afirmação do nosso controle instrumental sobre a realidade social por meio do direito (e da política).

Apesar dessa implicação problemática do consequencialismo jurídico, a renúncia à correspondente atitude é normativamente questionável e praticamente inviável. Por mais que não possamos ou não queiramos identificá-las, as decisōes judiciais têm consequências, reconhecidamente. Exigir dos juízes que se abstenham, na justificação das suas decisões, de considerar as consequências associadas às mesmas e às suas alternativas, significa reservar exclusivamente aos órgãos do Poder Legislativo e do Poder Executivo essa possibilidade. A exigência não é de todo absurda. Dependendo da concepção que se tenha acerca da função ou das funçōes que caberiam ou deveriam caber ao sistema jurídico na sociedade moderna (e. g., estabilização de expectativas normativas generalizadas) e dos obstáculos específicos ao desempenho de tais funções em países nos quais a ideia de estado de direito não fincou raízes profundas na realidade institucional, há algo de tentador na proposta de uma divisão radical do poder do Estado na qual o papel do juiz é reduzido ao de um aplicador inflexível e intransigente de programas condicionais (regras) de conteúdo semântico prefixado no que se refere às opções interpretativas. Contudo, esta é uma posição sustentada, na melhor das hipóteses, em argumentos especulativos e em apostas pessoais. A remissão a estados de confiança coletivos, a correspondências rígidas entre tipos de questōes jurídicas a resolver e instituições, ou a comparações entre graus de confiabilidade circunstancialmente atribuídos pelos cidadãos aos órgãos representativos de cada um dos três poderes estatais (saída para a qual parecem apontar alguns autores que pretendem assegurar, em alto estilo e com justiça, maior dignidade ao formalismo jurídico), apenas torna explícito o nó cego de uma proposta normativa que até agora não logrou, e dificilmente terá como cobrir a contento, um déficit argumentativo de natureza empírica.

Mas a referida exigência de abstenção enfrenta também problemas em certo sentido mais profundos e de ordem completamente diversa. Decisōes judiciais têm consequências extrajurídicas e intrajurídicas. Estas são as consequências que as decisōes produzem em termos de restriçōes ou extensões do espaço juridicamente aceitável para decisóes futuras. Consequências intrajurídicas ocorrem a reboque das implicaçōes materiais que se ligam ao conteúdo semântico das decisōes e dos argumentos afirmados como seus fundamentos, i. e., na forma de conclusões de inferências materialmente válidas que incluem as decisōes, junto com os argumentos em questão, como suas premissas; ${ }^{14}$ e o principal mecanismo que torna racional e juridicamente

14 O termo "inferência materialmente válida" está sendo utilizado no sentido e no contexto da teoria de Robert Brandom (v. Making it Explicit. Reasoning, Representing and Discursive Commitment, Harvard, 1994, Caps. 2 e 3). Trata-se das inferências válidas em razão do significado das expressōes não lógicas que aparecem nas suas premissas e conclusōes. 
obrigatória a aceitação de tais consequências por parte do decisor, e possivelmente outros decisores no futuro, é o princípio da isonomia (ou "justiça formal"), que perpassa o sistema jurídico reclamando consistência entre decisões, é dizer, tratamento juridicamente semelhante para casos semelhantes. A cobrança por consistência institui no processo decisório do juiz uma orientação prospectiva. Não se trata, com efeito, somente de buscar uma decisão para o caso concreto que não se afaste das decisões tomadas em casos concretos semelhantes no passado. Além disso, o decisor tem que ser capaz de perceber sua decisão enquanto precedente para decisões futuras. $\mathrm{O}$ juiz deve confrontar-se com o futuro como cenário de vigência de um conjunto de decisões relativo a uma classe de atividades e situaçōes, decisões cujas consequências agregadas ele não poderá simplesmente ignorar. ${ }^{15} \mathrm{Na}$ passagem das consequências para as partes às consequências associadas a uma classe de eventos assimiláveis a partir de um critério de relevância, começa a tornar-se insustentável uma cisão radical entre consequências extra e intrajurídicas, uma vez que a determinação das últimas (e.g., as consequências para a fixação dos limites da proteção jurídica conferida por um dado direito subjetivo) passa a depender, em parte, da tentativa de antecipação das primeiras (e. g., em qual medida esses limites podem ter sido afetados pelos incentivos que o conjunto de decisōes em questão produz em relação aos sujeitos nominalmente titulares do direito subjetivo).

Essa dependência é intensificada quando as consequências downstream da decisão colocam em risco a sua validade jurídica e, eventualmente, sua existência enquanto norma jurídica. Quando a realidade é tal que subtrai completamente à decisão as condiçōes para a sua eficácia, cabe questionar se seria de fato justificável a atribuição à mesma - i. e., ao "ato de vontade" do juiz, por ela veiculado - da "força ilocucionária" (do sentido pragmático) de um "dever-ser objetivo" do tipo jurídico (dever-ser ${ }_{\text {obj }}$ ) ${ }^{16}$ Esse questionamento está baseado na seguinte ordem de ideias: (a) o tratamento, de uma perspectiva socialmente generalizada, do sentido pragmático de um ato de vontade como dever-ser ${ }_{\text {obj }}$ institui a norma jurídica; (b) a atribuição desse sentido pragmático específico implica que se está presumindo que aquele a quem se imputa o ato de vontade seja alguém (b.i) que

15 Cf. a respeito Frederick Schauer, Precedent, Stanford Law Review, 39, p. 571-605 (588), 1987: "the conscientious decisionmaker must recognize that future conscientious decisionmakers will treat her decision as precedent, a realization that will constrain the range of possible decisions about the case at hand. If the future must treat what we do now as presumptively binding, then our current decision must judge not only what is best for now, but also how the current decision will affect the decision of other and future assimilable cases. Thus, the current decisionmaker must also take into account what would be best for some different but assimilable events yet to occur. The decisionmaker must then decide on the basis of what is best for all of the cases falling within the appropriate category of assimilation". Ver também R. Posner, Economic Analysis of Law, Aspen, 7. ed., p. 26 (esse argumento permanece sendo válido mesmo em sistemas jurídicos em que os precedentes judiciais carecem do poder de vinculação que possuem nos sistemas jurídicos de países como os EUA). Ainda, MacCormick, On Legal Decisions and their Consequences: From Dewey to Dworkin, NYU Law Review, 58, 1983, p. 239-258.

16 Ver a respeito deste argumento, Schuartz, A Práxis Recalcada na Teoria da Norma de Kelsen, em Norma, Contingência e Racionalidade: estudos Preparatórios para uma Teoria da Decisāo Jurídica, Renovar, 2005, p. 1-61. 
pode prestar contas em relação à autorização normativa que lhe confere a legitimidade para prescrever a terceiros, do modo como o fez, como estes deveriam comportar-se, e (b.ii) que é capaz de tornar verdadeiro em um número razoável de casos particulares, por si ou por meio de um "aparato coercitivo" (ao qual pode estar funcionalmente ligado em razão do cargo), se necessário recorrendo ao uso da força, o conteúdo semântico associado ao ato de vontade; e (c) o tratamento de fato, de uma perspectiva socialmente generalizada, do sentido pragmático de um ato de vontade como dever-ser ${ }_{\text {obj }}$ será justificado, e a norma daí resultante será válida, se e só se as duas condições (b.i) e (b.ii) forem verdadeiras, ou seja, se e somente se for verdadeiro que (b.i') aquele a quem se imputa o ato de vontade estiver realmente autorizado a determinar como deve ser o comportamento dos outros da maneira como o fez, e (b.ii') este alguém (ou outro alguém designado para o mesmo fim) for realmente capaz de garantir ao ato de vontade - ou melhor, ao comportamento que está sendo ordenado por meio do ato de vontade - um "mínimo de eficácia".

Se pensarmos no conceito de validade como aplicável a situaçōes sociais em que o sentido pragmático de um dever-ser ${ }_{o b j}$ é corretamente atribuído a uma determinada decisão a partir de uma perspectiva socialmente generalizada, então poderemos enxergar no mínimo de eficácia kelseniano o estado de coisas que evidencia, complementarmente à existência de um "fundamento de validade", a justificativa para a referida atribuição. A capacidade de fazer realizar, inclusive mediante o uso da força, o conteúdo semântico da decisão a que se atribui o sentido pragmático de norma jurídica, figura, portanto, na qualidade de elemento constitutivo desse sentido, também como condição para que se possa avaliar como correto o tratamento de algo como possuindo esse sentido. Mas trata-se de uma condição de natureza distinta da representada pela possibilidade (também implicada pela natureza específica do sentido pragmático de norma jurídica) de fornecer razōes que apontam para a existência de autorização normativa para a decisão. Kelsen estava certo ao estabelecer uma diferenciação entre essas duas distintas condições de sucesso pragmático, correspondente à diferenciação entre os significados que assumem, neste contexto, as questões acerca do "fundamento de validade" e da "condição de validade". Tanto a possibilidade de explicitação da autorização normativa upstream como a capacidade de garantir o mínimo de eficácia downstream são elementos constitutivos do conceito de validade jurídica, posto que são ambos constitutivos do conceito mais elementar de norma jurídica - ainda que a contribuição de cada um para a determinação do conteúdo semântico deste conceito seja completamente diferente. No nível mais elementar, a existência de uma norma jurídica dependerá da instituição e estabilização de uma situação social na qual, a uma determinada decisão, se atribui, de uma perspectiva socialmente generalizada, um sentido pragmático específico, que exibe os atributos de um dever-ser ${ }_{\text {obj }}$. Sem tais instituição e estabilização tende a desaparecer por inteiro a situação social apenas diante da qual está-se realmente autorizado a indagar a 
respeito da adequação do tratamento de algo como norma jurídica, i. e., a respeito da validade da norma jurídica instituída daquela maneira.

Decisōes tomadas por pessoas juridicamente competentes e em conformidade com os procedimentos aplicáveis sempre produzem algum impacto na realidade, e nesse sentido são sempre "eficazes". Esse impacto, porém, pode não ser aquele materialmente implicado pelo conteúdo semântico da decisão ou da norma geral que aquela pretende ter "aplicado" ao caso concreto. A realidade que sabota sistematicamente a implementaçāo de um objetivo nominalmente previsto em uma norma geral sabota simultaneamente a implementação das decisões individuais que a invocam nominalmente enquanto fundamento para a solução de litígios particulares. A impotência da norma em face da realidade comunica-se às decisões que almejam aplicá-la, as quais serão ineficazes no sentido da concretização da norma e nos seus próprios termos, mas eficazes na produção de um estado de coisas não expressamente autorizado e eventualmente ilegítimo (pense-se, por exemplo, na possibilidade de criação e estabilização de privilégios para um determinado grupo de pessoas, resultantes de decisões judiciais que lhes foram favoráveis e que se fundamentam em uma liberdade ou um direito nominalmente universal, mas cuja fruição efetivamente generalizada depende de condições materiais inexistentes).

Se, portanto, de um lado, a racionalidade jurídica de uma decisão parece depender, constitutivamente, de uma investigação prospectiva - ainda que tateante - das suas futuras consequências, incluindo as extrajurídicas; mas, de outro, o controle ex ante das condições de racionalidade instrumental da decisão deverá permanecer, salvo em casos excepcionais, refreado, coloca-se naturalmente a questão acerca de onde localizar critérios de adequação que serviriam para viabilizar críticas e consensos racionais endereçados especificamente à parte consequencialista da fundamentação das decisões. A meu ver, respostas plausíveis a essa questão possuirão um núcleo comum que incluirá os seguintes dois componentes: em primeiro lugar, a referência a um objetivo compartilhável, que possibilite valorações não partidárias das consequências associadas a uma dada decisão judicial e às suas alternativas disponíveis. Supondo, excepcionalmente, que objetivos e valores particulares já não tenham sido prefixados nas normas jurídicas aplicáveis ao problema sub judice (como por exemplo se verifica nas hipóteses de implementaçāo de princípios constitucionais), meu candidato ao papel é a maximização do bem-estar social, mensurado este a partir de algum mecanismo não reducionista e minimamente operacional de agregação das preferências subjetivas das pessoas afetadas pela decisão e por suas alternativas - desnecessário ressaltar, uma escolha ciente do Teorema da Impossibilidade de Arrow. O mecanismo tem que ser operacional no sentido de apenas exigir, para sua implementação em procedimentos judiciais, informações (ou proxies confiáveis das mesmas) que possam ser obtidas, por decisores limitadamente racionais, a um custo aceitável; e deve ainda ser não reducionista, no sentido específico da resistência a assimilações ligeiras do conceito de bem-estar social ao conceito de eficiência econômica (ou pior, ao conceito de riqueza agregada). Isso 
não significa que a assimilação esteja vedada (mesmo porque há um trade-off entre não-reducionismo e operacionalidade), mas que a identificação entre estes conceitos não deve ser o estado default; ao contrário, ela requer a superação de um ônus argumentativo não trivial. Preocupações distributivistas só devem ser retiradas do Poder Judiciário quando houver boas razōes particulares para fazê-lo, nāo em nome de resultados teóricos que confiem abstratamente, a alguma política fiscal, a redistribuição da riqueza que decisōes judiciais prévias contribuíram para concentrar de maneira socialmente indesejada.

Em segundo lugar, uma resposta apropriada à questão colocada previamente deverá conferir uma posição central à dogmática jurídica na atividade de domesticação dos juízos acerca das relaçōes de determinação entre decisōes possíveis e consequências. Esta é uma ideia que provavelmente soará estranha à primeira vista, e que recomenda uma explicação mais completa. Em um trabalho seminal, Niklas Luhmann aponta a "proibição da negação" (Negationsverbot), a "inegabilidade dos pontos de partida das cadeias de argumentação" (Nichtnegierbarkeit der Ausgangspunkte von Argumentationsketten), como um atributo que condiciona, mas não caracteriza, a função social da dogmática jurídica. ${ }^{17}$ Contrariamente às aparências, tal função consistiria justamente no incremento do grau de liberdade no trato com "experiências e textos", "permitindo distanciamento também e precisamente ali onde a sociedade espera vinculação". Esse "aumento das inseguranças" que a dogmática viabiliza é, não obstante, sempre algo controlado: somente as "inseguranças suportáveis" (tragbarer Unsicherheiten) é que podem ser intensificadas, entendendo-se por tais, neste contexto, as inseguranças compativeis com duas "exigências centrais" do sistema jurídico, quais sejam, a da vinculação às normas jurídicas e a da obrigatoriedade da tomada de uma decisão diante dos conflitos jurídicos. O problema, e este é um dos grandes achados de Luhmann sobre o assunto, verifica-se quando, nos processos de aplicação do direito, ambos os elementos da relação, i. e., tanto as normas jurídicas (em virtude da positivação do direito e das liberdades envolvidas na sua interpretação), quanto os casos concretos a que seriam aplicadas, passam a ser contingentes, e o processo de aplicação "perde o ponto fixo de referência em um dos seus elementos". Nessas circunstâncias, a referência perdida tem que ser substituída por um critério que governe o movimento de ir e vir entre as normas e os fatos e imponha limites ao capricho do aplicador na seleção das variações que se tornaram em princípio possíveis com a bilateralidade da contingência. É então para a provisão de critérios deste tipo que surge a necessidade da dogmática jurídica.

O exercício dessa atividade de controle e, com ele, o surgimento e a estabilização de uma dogmática jurídica, são seriamente comprometidos pelo consequen-

17 Cf. Luhmann, Rechtssystem und Rechtsdogmatik, Kohlhammer, 1974, p. 15-18. Para este e o subsequente parágrafos, ver também o restante do Cap. II e o Cap. IV, que trata, especificamente, do uso de consequências como critérios decisórios. Acerca da diferença entre Konditionalprogramme e Zweckprogramme ("programas condicionais" e "programas finalísticos"), ver as observações do mesmo autor em Das Recht der Gesellschaft, Suhrkamp, 1995, p. 195-204. 
cialismo jurídico e os "programas finalísticos" que o acompanham. Não surpreende que, nos terrenos nos quais o fenômeno se fez sentir de maneira mais intensa e generalizada (especificamente, nas áreas do direito em que foi mais amplo o processo da sua constitucionalização), tenha-se assistido à demolição das antigas construçōes dogmáticas e à sua substituição por um discurso pouco diferenciado, em que ocasionalmente podemos nos deparar, lado a lado, e em pé de igualdade, com referências a textos normativos, precedentes judiciais, doutrinas jurídicas estrangeiras, visões do mundo, pedaços de teorias científicas, filosóficas e obras poéticas, e outros itens de um acervo histórica e tematicamente ilimitado. Na falta da disciplina discursiva imposta pela dogmática jurídica, virtualmente qualquer coisa é aproveitável como premissa em um argumento destinado a bancar uma dada decisão judicial. Sem essa disciplina, as liberdades hermenêuticas correm soltas, o conjunto das decisões juridicamente admissíveis torna-se indeterminado e a insegurança jurídica, patologicamente "insuportável". Há realmente boa dose de razão na intuição normativa por trás da crítica econômica a um consequencialismo meio justiceiro que se tem presenciado no Brasil em alguns exemplos de revisão judicial de contratos privados e relativização de direitos de propriedade, embora o consequencialismo pró-eficiência recomendado como o sucessor supostamente mais ilustrado do ponto de vista acadêmico sofra exatamente do mesmo mal. A reconquista de estabilidade nas expectativas normativas e de uma relativa previsibilidade das decisões, justamente reclamadas sobretudo por agentes econômicos cujas ações devem ser planejadas e executadas em um ambiente já caracterizado por elevado grau de incerteza, nāo pode ser garantida simplesmente trocando-se uma finalidade normativa pela outra. O problema, que é comum a ambas, está no fato da orientação consequencialista ela própria, $i$. e., na dependência, da licitude da expectativa e da correção da decisão que a confirmará ou desconfirmará, em relação a algo que somente ocorrerá no futuro - e não na escolha do valor particular que conduzirá a decisão enquanto seu ponto de referência normativo.

Melhor destino não cabe à diretriz formalista do "consequencialismo de regras" que, salvo engano, é um pressuposto dos receituários para o crescimento econômico baseados na instigante "teoria das origens legais". ${ }^{18} \mathrm{Na}$ versão mais simples, a diretriz é incontroversa, mas paga por isso o preço da total falta de operacionalidade jurídica. De fato, "respeito aos contratos e proteção aos direitos de propriedade" converte-se em uma fórmula vazia quando confrontada com a realidade dos contratos incompletos e carentes de interpretação e com os atributos da sobre e subinclusividade que caracterizam as situaçōes de aplicação de regras simples a casos concretos. $\grave{A}$ medida que for incorporando as qualificaçōes pertinentes, contudo, a referida fórmula irá elevando, pari passu, o número de hipóteses não triviais dos modelos que deveriam governar sua utilização, e, com ele, a complexidade dos processos de decisão correspondentes, até o ponto em

18 Para uma visão panorâmica e recente da teoria das origens legais, cf. La-Porta, Lopez-de-Silanes e Shleifer, The economic consequences of legal origins, acessível no sítio do National Bureau for Economic Research, Working Paper \#13608, 2007. 
que a diretriz formalista se dissolve (ou seja, deixa de existir um conjunto de regras gerais cujo uso, na maioria dos casos, pudesse justificar-se por meio de argumentos consequencialistas de segunda ordem), retornam as demandas por justificaçōes consequencialistas pontuais para cada decisāo individual a tomar, e a proposta novamente sucumbe por falta de operacionalidade. A razão já foi exposta no final da seção precedente, valendo a pena recordá-la neste contexto particular: as informaçōes necessárias para uma aplicação metodologicamente rigorosa da teoria normativa relevante (e. g., alguma das teorias econômicas mais recentes e sofisticadas acerca do direito contratual) não estarão disponíveis ao juiz ou a terceiros antes da tomada da decisão, com o que a teoria perde sua capacidade de fornecer critérios objetivos de decisão que possam ser usados pelo decisor ou por aqueles aos quais o decisor deveria prestar contas a respeito da adequação jurídica da alternativa de decisão escolhida. ${ }^{19}$

A delicada operação de reconciliação entre dogmática jurídica e consequencialismo jurídico requer, inicialmente, a ampla condicionalização das normas de direito positivo que se apresentem na forma de prescriçōes da realização de objetivos (e.g., princípios jurídicos ou "programas finalísticos"), i.e., sua reestruturação enquanto normas do tipo "Se $\mathbf{X}$, então dever-ser ${ }_{\text {obj }} \mathbf{Y}$ ", seguida pela redescrição da condição $\mathbf{X}$ de modo que a verificação da sua ocorrência pelo julgador nos casos concretos dependa, predominantemente, da investigação de fatos pretéritos à conduta sub judice. Um exemplo bastante sutil de como isso pode ser feito (bem como das dificuldades e dos riscos envolvidos) encontra-se no direito de defesa da concorrência, em que prescrições de objetivos de difícil operacionalização em processos de aplicação do direito (e. g., a maximização do bem-estar social no controle de concentrações econômicas) foram sendo substituídas por regras

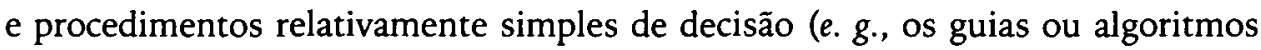
de análise, mundialmente difundidos, elaborados pelas autoridades competentes) cuja implementação, por sua vez, é substancialmente dependente do recurso a fatos passados para a enunciação de prognósticos acerca de eventos futuros ${ }^{20}$ (e. g., a consideração dos volumes de importações passadas como prova de que importaçōes futuras serão capazes de inibir exercícios de poder de mercado pelas firmas participantes na concentração avaliada).

A expressão “dogmática jurídica” deverá ser entendida no presente contexto em um sentido funcional, precisamente, como qualquer conjunto de proposições que, ancorado na ideia da "proibição da negação dos pontos de partida", se propo-

19 Para uma opiniāo similar com respeito à análise econômica do direito contratual, ver E. Posner, Economic Analysis of Contract Law after Three Decades: Success or Failure?, The Yale Law Journal, $112,4,2003$, p. 829-880. Para uma posição mais otimista e crítica quanto às conclusões do artigo de Posner, cf. Craswell, In That Case, What Is The Question? Economics and the Demands of Contract Theory, The Yale Law Journal, 112, 4, 2003, p. 903-924. Cf. ainda S. Breyer, Economics and Judging: An Afterward on Cooter and Wald, Law and Contemporary Problems, 50, 1987, p. 245-252.

20 Ver Schuartz, Quando o Bom é o Melhor Amigo do Ótimo, Revista de Direito Administrativo, 245, 2007, p. 96-127. 
nha a executar a função de condicionalização já referida acima. ${ }^{21}$ Isso é fundamental para conferir ao direito a posição de "domínio limitado", ${ }^{22}$ i. e., de um jogo cujos lances autorizados devam realizar-se dentro de fronteiras previamente delineadas, ainda que de forma difusa. A afirmação de que o direito é um domínio limitado pode ser recebida como uma hipótese empírica ou uma proposição normativa. A depender do caso, a convicção é que existiriam no direito argumentos que não contam ou devem contar, incluindo argumentos que contariam e deveriam contar em outras esferas sociais nas quais são discutidas questōes importantes relacionadas à racionalidade e à legitimidade de decisōes vinculantes e normas (e. g., a esfera da política). Essa convicção pode expressar-se na forma de reconstrução de uma "regra de reconhecimento" implícita na práxis comunicativa dos participantes do jogo do direito (como, por exemplo, em Hart), ou em tentativas de diferenciação substantiva que evitem compromissos quanto à existência de um "pedigree" que fosse próprio às normas jurídicas (como por exemplo em Dworkin, com a sua distinção entre "arguments from principle" e "arguments from policy"). A espécie de reconciliação entre dogmática e consequencialismo que está sendo vindicada neste artigo é harmonizável com qualquer destas concepções e com várias de suas possíveis modificaçōes e combinaçōes, dado que as operaçōes de condicionalização dos programas finalísticos que ela requer não incidem diretamente sobre normas, mas sobre as atividades de aplicação das normas nos casos concretos. ${ }^{23}$ Do menu de teorias do direito que se posicionam a respeito das condições de racionalidade de decisões judicantes, incompatibilidades de princípio com este tipo de exigência parecem existir somente com relação à vertente mais romantizada do pragmatismo jurídico, que vê o juiz exemplar no visionário disposto a se lançar, inventiva e experimentalmente, em direção a um futuro desconhecido, a fim de escolher o que acredita ser a melhor decisão do ponto de vista da sociedade e alheio a preocupa-

21 Esse entendimento requer que a dogmática jurídica possua uma dimensão "fracamente normativa", i. e., que ela se ocupe ao menos da apresentaçāo (baseada em métodos empírico-analíticos ou hermenêuticos) do direito válido em um determinado momento histórico e lugar, tendo em vista a preparação das premissas normativas para as inferências que sustentam as decisōes. Isto é perfeitamente compatível com concepçōes mais ricas ou "multidimensionais" da dogmática jurídica ou da ciência do direito (cf., por exemplo, nessa linha, Ralf Dreier, Zum Selbstverständnis der Jurisprudenz als Wissenschaft, 1971, em Recht - Moral - Ideologie, Suhrkamp, 1981, p. 48-69).

22 Cf. nesse sentido Frederick Schauer, The Limited Domain of the Law, Virginia Law Review, 90, 7 , 2004, p. 1909-1956.

23 Uma possível ilustração nesse sentido é dada pela Gewichtsformel de Robert Alexy, se a entendermos como um método geral para a aplicaçāo de princípios ("mandamentos de otimização") e a solução de conflitos entre os mesmos. Cf. Alexy, Constitutional Rights, Balancing and Rationality, Ratio Juris, 16, 2, 2003, p. 131-140. Ver a respeito Schuartz, Nos Limites do Possível: "Balanceamento" entre Princípios e o Controle de sua Adequaçāo na Teoria de Robert Alexy, Norma, Contingência e Racionalidade, p. 179-228, onde manifesto meu ceticismo quanto à fórmula proposta por Alexy para assegurar objetividade aos processos de ponderação de princípios. Para uma defesa desta fórmula enquanto garante da racionalidade desses processos, ver Carlos Bernal Pulido, The Rationality of Balancing, Archiv für Rechts-und Sozialphilosophie, 92, 2006, p. 195 e seguintes. Para uma crítica da recepção da teoria dos principios de Alexy no Brasil, ver Virgílio Afonso da Silva, Princípios e regras: mitos e equívocos acerca de uma distinção, Revista Latino-Americana de Estudos Constitucionais, 1, 2003, p. 607-630. 
ções com a geração de descontinuidades no fluxo das expectativas normativas. ${ }^{24} \mathrm{O}$ julgador pragmático não se detém perante textos normativos, não aceita restrições no universo dos insumos disponíveis para a justificação das decisōes, e faz do direito positivo, da dogmática jurídica, bem como das teorias e estratégias gerais de aplicação do direito (e. g., do formalismo), eles próprios, objetos de sua escolha, convertendo-os em "fontes de informação" e em ferramentas cujo emprego apenas deverá justificar-se instrumentalmente, vale dizer, em funçāo da sua maior ou menor contribuição para a produção pontual da consequência tratada como a melhor do ponto de vista social. No pragmatismo jurídico, portanto, a reconciliação entre dogmática e consequencialismo é opcional e se subordina à visão do decisor sobre os interesses sociais relevantes para o caso.

Idealmente, a racionalidade dessas operaçōes de reconciliação dependeria da opção por programas condicionais cuja aplicação tendesse a produzir, no agregado, consequências no mínimo tão socialmente desejáveis quanto aquelas produzidas por decisōes diretamente orientadas na produção da consequência ótima em cada situação. Mas os obstáculos nesse sentido são exatamente os mesmos que os anteriormente identificados com relação às várias recomendações mais ou menos formalistas do uso de heurísticas e regras frugais de decisão por razões de natureza consequencialista. Nós simplesmente não sabemos o suficiente para determinar empiricamente e para comparar normativamente as consequências globalmente relacionadas à adoção de uma ou outra estratégia de segunda ordem. Nessas circunstâncias, parece-me que o melhor a fazer é garantir pelo menos um grau elevado de objetividade e de previsibilidade aos juízos em que se sustentam as decisōes e, por essa via, de segurança às expectativas daqueles que vierem a ser por elas diretamente afetados. É claro que os ganhos esperados de objetividade, previsibilidade e segurança podem dar-se precisamente às custas das consequências que se queria realizar por meio dessa opção. Mas a consciência desses riscos por parte do decisor $e$ dos outros (afetados ou não afetados pela decisão), de um lado, e as implicações dessa consciência em termos da discussão acerca dos critérios de escolha das pessoas competentes para tomá-las, de outro lado, devem sem dúvida ser contabilizados como ganhos de racionalidade em comparação a um estado de coisas em que alguns creem saber o que não sabem e reclamam para si, baseados nessa conviç̧ão, o poder de obrigar os demais, sem o seu livre consentimento, a suportar os riscos associados a decisões que talvez preferíssemos entregar ao cuidado de pessoas que podemos eleger e substituir em processos transparentes e democráticos. ${ }^{25}$

24 O mais notável jurista a recentemente encampar o pragmatismo jurídico foi Richard Posner. Isso significou sensíveis mudanças na concepção de Posner acerca do direito e da função jurisdicional. Ver, do mesmo autor, Overcoming Law, Harvard, 1995, e Law, Pragmatism and Democracy, Harvard, 2003. A respeito, Elisabeth Krecké, Economic Analysis and Legal Pragmatism, International Review of Law and Economics, 23, 2004, p. 421-437.

25 “Man muss [...] damit rechnen, dass die Juristen dann mangels dogmatischer Kontrollen nicht mehr in der Lage sein werden, im Prozess der Abwägung der Folgen ihrer Entscheidungen zwischen ihrer wertenden Erwartungen und ihrer Kriterien ausreichend zu differenzieren; und damit würden die politische Kontrolle des Zugangs zur Rechtsentscheidung und die Personalauswahl derer, die 


\section{Três tipos ideais de um consequencialismo jurídico à brasileira: consequencialismo festivo, militante e malandro}

A principal finalidade desta seção é apresentar tentativamente três tipos ideais para a descrição e a investigação empírica de atitudes consequencialistas no direito. Não se trata de uma listagem exaustiva de categorias nem tampouco, evidentemente, de uma tipologia com pretensões de exclusividade. A ideia é propor um conjunto de conceitos que possam servir para iluminar de forma exploratória uma realidade complexa e multifacetada e que, ao mesmo tempo, tenham um elevado valor empírico no sentido de recortar o fenômeno do consequencialismo jurídico em fatias representativas do comportamento efetivo dos agentes que participam do sistema jurídico nos mais diferentes papéis (advogados, juristas, juízes etc.). $\mathrm{O}$ sucesso da proposta de classificação nesta segunda dimensão requererá uma análise cuidadosa de fatos (não apenas de natureza documental, como decisões judiciais ou artigos acadêmicos) capazes de indicar atitudes (ou posicionamentos) que governam estratégias de argumentação voltadas à justificação de decisōes judicantes. De que tipo seriam esses fatos, onde buscá-los, como avaliá-los etc. são questōes metodológicas sobre as quais o presente artigo nada diz. Minha aposta é que poderão ser respondidas sem maiores dificuldades por pesquisadores interessados em estudar o fenômeno do consequencialismo jurídico no Brasil de uma perspectiva sociológica. O desafio, por ora, é mapear o terreno conceitual, e é a isso que se dedica o resto do texto.

"Festivo", "militante" e "malandro" são expressões a que não se está atribuindo uma carga valorativa necessariamente negativa. Especificamente, o valor normativo de cada um destes três tipos de consequencialismo jurídico dependerá das circunstâncias. Mesmo sem perder de vista a "insegurança patológica das expectativas normativas" enquanto estado de coisas a evitar pelo sistema jurídico, não me parece que seria apropriada uma atitude rígida de reprovação perante qualquer dos tipos. Talvez não seja exagerado afirmar que, seja qual for a finalidade que se pretenda imputar ao direito, haverá circunstâncias que autorizarão o recurso, a pelo menos uma das três formas de consequencialismo jurídico, como apropriado para a implementação da finalidade imputada. Entretanto, as dificuldades de se determinar em geral e em concreto essas circunstâncias, e a suspeita de que seriam muito excepcionais, recomendam a adoção de uma presunção relativa de ilegitimidade para cuja superação seja definido um substancial dever de prestação racional de contas que inclua tanto argumentos empíricos (para mostrar que a estratégia de decisão é a mais apropriada para a realização do objetivo escolhido), quanto argumentos normativos (para mostrar que é adequada a escolha

über Recht und Unrecht entscheiden, zum Problem werden. Letzten Endes würde es dadurch sinnlos werden, zwischen den Disjunktionen von rechtmässig/rechtswidrig und gut/schlecht noch zu differenzieren - eine Differenz, für die Sokrates gestorben ist" (Luhmann, Rechtssystem und Rechtsdogmatik, p. 48). Ver também Schuartz, Die Hoffnung auf radikale Demokratie, Cap. VI, parte final. 
deste objetivo e não de outros que poderiam comprometer a conclusão acerca da relação de causalidade). Isso é bem mais fácil dizer do que fazer. A razão não está somente no abismo existente entre definir um dever nestes termos e garantir-lhe o mínimo de eficácia. Em cima disso, há problemas com a própria razoabilidade do dever. O mais sério deles deriva do fato de algumas estratégias consequencialistas de argumentação, que teriam que ser, como tais, explicitadas e justificadas perante terceiros de acordo com o referido dever de prestação de contas, possivelmente exibirem condiçōes de sucesso incompatíveis com o cumprimento do dever. Sobretudo no caso do consequencialismo malandro - o mais sofisticado dos tipos -, pode ocorrer de o êxito da argumentação depender de truques retóricos que não devam ser tornados explícitos a algum dos participantes da situação de decisão. Como nos espetáculos de mágica, o segredo do truque permanece com o mágico; mas, adicionalmente, à plateia não caberá ser nem mesmo revelado que se tratava de um truque. Se essa espécie de tática decisória mereceria, no estado democrático de direito, redenção pelas circunstâncias, é uma questāo filosófica que me permitirei não abordar no âmbito deste artigo. O ponto a destacar é sua disponibilidade, não apenas para advogados e juristas, mas também para a autoridade estatal competente para decidir.

Os três tipos de consequencialismo jurídico listados acima possuem semelhanças e diferenças suficientemente importantes para servirem de pontos focais para a classificação e guiarem o trabalho de caracterização. $O$ que as atitudes festiva, militante e malandra têm em comum, enquanto tipos de consequencialismo jurídico, é a oposição de resistência aos resultados de decisões alternativas às preferidas e determinadas por aplicações prosaicas de regras jurídicas. Tal como concebidas, estas três estratégias de argumentação entram em cena se, e quando, a solução de um caso concreto, a partir de regras prima facie aplicáveis, conduzir a uma decisão com resultados diferentes dos desejados pelo usuário da estratégia, independentemente da motivação deste último. Note-se que essa caracterização não assume que o objeto contra o qual será articulada a resistência consequencialista seja algo próximo à "única decisão correta" para o caso, ou mesmo, à decisão correta tendo em vista as regras supostamente aplicáveis. A condição enunciada é bem mais fraca, considerando suficiente a existência de regras que suportem, sem apelar a consequências, uma decisão juridicamente plausível. É para afastar decisões como esta, que, além disso, produzam resultados distintos dos desejados pelo decisor ou por outros participantes da situação de decisão, que se monta a estratégia consequencialista. Diversamente, se a menção às consequências das diferentes alternativas de decisão (incluindo aquela mais preferível pelo usuário da estratégia) tiver o objetivo de privilegiar, na solução do caso concreto, a aplicação de um conjunto particular de regras em detrimento de outros tratados como igualmente defensáveis do ponto de vista jurídico (uma estratégia que chamaremos, seguindo a sugestão introduzida na Seção 1, de "consequencialismo residual"), estar-se-á perante casos apenas parcialmente cobertos pelas considerações que seguem. 
As diferenças entre os tipos serão definidas em função do grau de reverência formal à dogmática e às figuras tradicionais da argumentação jurídica, principalmente o raciocínio analógico e o respeito ao precedente. Em uma escala crescente, a posição inferior é ocupada pela estratégia "top-down" e dedutiva que é própria ao consequencialismo festivo. De fato, uma das suas principais características é o desdém - e um certo desprezo - com relação ao modo convencional de solução de problemas jurídicos praticado profissional e usualmente por juristas e juízes e treinado nas faculdades de direito. No lugar da atualização de técnicas que parecem arrastar-se, anacrônica e irracionalmente, pelas vias do ensino e das profissões jurídicas, o consequencialismo festivo advoga uma ampla des-diferenciação entre aplicação do direito e formulação de políticas públicas, comandada por uma apropriação superficial e seletiva da literatura norte-americana de análise econômica do direito. São especialmente os dois atributos, a saber, a atitude crítica e desdenhosa diante da prática dos juristas e juízes, e a superficialidade e seletividade na escolha dos seus insumos teóricos e metodológicos, que no Brasil conferem ao consequencialismo festivo um ar caricatural quando comparado com seu maior modelo inspirador, cujas qualidade acadêmica e capacidade de racionalização do discurso politico são inquestionáveis. No âmbito do direito, a estória é outra, salvo em áreas muito específicas como, por exemplo, o direito de defesa da concorrência, no qual, como já exposto, os "mandamentos de otimização" foram domesticados por programas condicionais de manuseio intersubjetivamente controlável. É também por força desses dois atributos que o consequencialismo festivo, apesar da aparência e da ambição transformadora, é impotente e tende a funcionar entre nós como a mais jovial das ideologias conservadoras: impotente, pelo esoterismo e pela estranheza em relação ao modo de pensar e agir dos juristas e juízes; e ideológico-conservador, pela reatualização e a reprodução de um padrão de argumentação que expressa um dos mais antigos e persistentes vícios do pensamento jurídico no país: o da importação elitista para uso meramente ornamental, ao sabor dos caprichos e das veleidades do usuário, de fragmentos de doutrinas e teorias científicas e filosóficas que se encontram em voga nos centros culturais.

O valor positivo do consequencialismo festivo começa a aparecer quando cumpre o papel de corretivo com relação ao segundo dos tipos de consequencialismo acima referidos, qual seja, o militante. Assim como o primeiro, o consequencialismo militante caracteriza-se por não se deter diante das regras do direito positivo e não se preocupar em reestruturar as suas referências normativas na forma de programas condicionais prévia e cuidadosamente lapidados com as ferramentas da dogmática jurídica. No entanto, à diferença do festivo, o militante está mais alinhado à tradição e quer ancorar suas posições em normas, valendose, ao menos nominalmente, das formas canônicas de interpretação do direito. Isso explica, por exemplo, o previsível encantamento com a aplicação direta de princípios constitucionais e a "ponderação de interesses". É isso também que o faz alinhar-se aos vários movimentos de constitucionalização que aparentemente 
começam a predominar na produçāo de livros e de artigos jurídicos no país - em substituição à dogmática jurídica, que parece ir minguando à mesma velocidade. $\mathrm{O}$ apelo do consequencialismo militante vem dessa reverência nominal à Constituição, articulada em um discurso que combina, retoricamente, respeito à tradição e sua adaptação às necessidades do momento. Se a decisão judicial conforme a regras produz resultados que contrariam aquilo que exige um princípio constitucional, fica relativamente fácil defender a sua invalidade jurídica quando se assume adicionalmente que há algum tipo de hierarquia entre as regras e o princípio em questão. O problema está nos termos em que a proposição é enunciada e na verificação das suas condições de verdade. Nos processos de aplicação do direito, a invocação de relações não triviais de determinação entre alternativas de decisão e resultados tem o efeito de colocar o exercício da crítica pela razão instrumental em suspenso ${ }^{26} \mathrm{O}$ recurso às consequências, tipicamente, é a cartada coringa, lançada sobre a mesa de forma a conduzir a discussāo para um terreno no qual todos os gatos são pardos: o sujeito que faz uso do argumento não tem como prová-lo aos demais; mas estes tampouco poderão provar a sua negação. Fora do sistema jurídico, as incapacidades se compensam e a controvérsia terá que ser ou solucionada consensualmente com argumentos de outro tipo ou então deixada em aberto (como é usual no sistema científico). No direito, porém, a solução cabe à autoridade judicante competente, que decide pondo fim à controvérsia segundo o seu convencimento subjetivo. Quando, logo, quem milita é a autoridade julgadora, saltam aos olhos os riscos da parcialidade e do decisionismo arbitrário, riscos que o consequencialismo festivo pode ajudar a reduzir.

A vantagem do consequencialismo festivo sobre o consequencialismo militante está em que o primeiro encosta-se em teorias e métodos cientificamente credenciados, ao passo que o segundo opera teórica e metodologicamente desamparado. A aplicação entusiasmada, mas pouco rigorosa da ciência econômica, uma das marcas do consequencialismo festivo, não lhe retira a aptidão de referir-se $a$ ela para constranger seus oponentes na argumentação jurídica. Ainda que não prove rigorosamente as suas propostas positivas de associação entre alternativas de decisão e consequências, um pronunciamento solene de expressōes retiradas da literatura econômica poderia tornar manifesta, ao juiz, a fragilidade das suas convicções sobre a referida associação, induzindo-o, assim, a limitar-se a métodos mais familiares (não consequencialistas) de decisão. A argumentação festiva é capaz de alertar o julgador para o que este deveria saber a fim de afirmar com alguma certeza que tal consequência seguir-se-á de tal decisão e, como este conhecimento estará indisponível para resolver o litígio, inibir-lhe o impulso consequencialista.

Os déficits teóricos e metodológicos do consequencialismo militante revelam aquele que é o verdadeiro motor por trás das suas manifestações: a simpatia por uma determinada causa. Na militância judicial, particularmente, a causa é um valor abstrato representado por uma das partes do litígio, para a qual a decisão favorável

26 Cf. a parte final da Seção 1, supra. 
é uma questão de merecimento, ou seja, de justiça material. Há aqui, sem dúvida, um resquício de jusnaturalismo, embora sem qualquer apoio em um sistema filosófico que assegurasse à decisão um grau comparável de consistência. Em vez disso, seus fundamentos parecem advir de amálgamas entre visões do mundo, opiniões superficiais e ligeiramente informadas sobre a realidade e sentimentos de identificação e rejeição. $\mathrm{Na}$ dinâmica decisória, o momento crucial ocorre quando o decisor identifica a parte que, em concreto, representa a causa que foi abraçada. Posteriormente, a argumentação coloca-se a serviço da sua justificação, se necessário por meio de argumentos consequencialistas. Não se trata, propriamente, como sugeriam os realistas jurídicos, de uma racionalização ex post de decisões anteriormente tomadas com base em razōes ideológicas e extrajurídicas. O consequencialismo militante não se socorre de racionalizações com vistas à ocultação dos verdadeiros fatores determinantes da decisão; ao contrário, ele os explicita orgulhosamente. A relativização da força da lei é apresentada às claras, assim como a causa que a legitimaria pelos seus resultados e o valor que autorizaria a sua superior e definitiva reconciliação com o direito.

Apesar dos perigos da des-diferenciação entre as funções do juiz e do justiceiro que impõe aos demais, com maior ou menor violência, seu sistema de preferências, a militância judicial pode eventualmente exercer um papel não socialmente indesejável, dependendo das circunstâncias. Quanto mais amplamente compartilhável for o objetivo normativo a realizar (e. g., maximização do bemestar ou das liberdades públicas e privadas para o maior número possível de indivíduos), e mais distante estiver a decisão segundo regras da realização desse objetivo, menos questionável socialmente tende a ser a decisão que afastar a aplicação das regras em nome do objetivo que se pretendia implementar. Autênticas situações desse tipo podem efetivamente surgir e, quando surgem, o desfecho ideal é a construção dogmática de uma nítida distinção entre condições que acionam a regra, e condiçōes que autorizam uma exceção à regra, bem como a caracterização do caso concreto como exceção que mereceria o correspondente tratamento. É verdade que isso fará aumentar a complexidade dos futuros processos decisórios em situações semelhantes, que agora serão obrigados a alocar os fatos do caso sob o domínio da regra ou da exceção à regra; não obstante, esta complexidade não é do tipo que perturba o funcionamento do sistema jurídico, assumindo-se que as condiçōes de aplicação da regra e da exceção tenham sido bem especificadas. Também é verdade que a estratégia da previsão de exceções a uma regra traz consigo o risco do slippery slope; mas transitar por planos inclinados e escorregadios é um risco que às vezes deve ser confrontado e intencionalmente assumido. A questão é dizer quando, e a resposta será sempre função do valor que estiver em jogo no caso concreto e da capacidade dos demais atores institucionais (notadamente, o Poder Legislativo) de atender às demandas por novas regras que garantam, simultaneamente, decisōes mais plausíveis e maior segurança e estabilidade às expectativas normativas dos indivíduos. 
Infelizmente, o que se tem visto no Brasil é um quadro diferente. Não só florescem descontroladamente as decisōes baseadas diretamente em princípios constitucionais e em atribuições opacas de pesos a valores e interesses supostamente em conflito; ${ }^{27}$ além disso, não é visível uma reação proporcional dos juristas no sentido da contenção, pela dogmática jurídica, deste movimento expansionista. Está para ser elucidado o motivo pelo qual há no país tantos juristas que apenas reconhecem dignidade ao estudo do direito quando ele se mistura aos estudos da filosofia, da sociologia ou - mais recentemente - da economia. Seja qual for a explicação para tal atitude, o fato é que nunca careceu-se tanto de produção de dogmática jurídica quanto no presente. A cantilena dos princípios, que dá o acabamento ao consequencialismo militante, é, desprovida de dogmática, uma ameaça à segurança jurídica, e é difícil evitar a impressão de que o Judiciário, que deveria ser seu maior guardião, tenha, em diversos casos, fraquejado diante da tentaçāo de substituir-se a outros poderes públicos na formulação e implementação de políticas cuja necessidade poucos se atreveriam a negar. $O$ preço que a militância cobra em termos da geraçāo de inseguranças quanto à proteção de expectativas e direitos individuais pode ser bastante elevado sob tais condiçōes, sendo certo que, para a redução das mesmas, não existe um substituto à altura da função jurisdicional. $O$ juiz que faz uso do poder que lhe confere o direito para ponderar interesses na defesa de uma determinada causa da qual se apresenta como simpatizante, desatento aos mecanismos de autocontrole que só a dogmática jurídica poderia disponibilizar, lança-se longe demais e põe seriamente em risco justamente o único valor que lhe cabe defender intransigentemente no estado democrático de direito.

Consequencialismo com dogmática demanda um certo domínio do material jurídico. Talvez por isto seja característica dos melhores juristas brasileiros a capacidade para operar com fluidez nesta intersecção, inclusive quando tal capacidade deva manifestar-se enquanto criação de novas figuras dogmáticas que permitam resolver um caso no sentido desejado e contrariamente à maneira até então predominante de solução jurídica de casos semelhantes. É a esta hipótese que se refere a expressão "consequencialismo malandro". Diferentemente dos demais tipos de consequencialismo, a malandragem é uma estratégia argumentativa que se implementa necessariamente através da dogmática jurídica, mais especificamente, para a desconstrução e a reconfiguração dos elementos da argumentação na forma

\footnotetext{
27 Um problema que, aparentemente, não ocorre só em países com características institucionais similares às do Brasil. Para os EUA, ver Charles Fried, Two Concepts of Interest: Some Reflections on the Supreme Court's Balancing Test, Harvard Law Review, 72, 4, 1963, p. 755-778; e T. Aleinikoff, Constitutional Law in the Age of Balancing, The Yale Law Journal, 96, 5, 1987, p. 943-1005. Na Alemanha, críticas diante da ideia de ponderação de interesses, valores ou bens, remontam a Rudolf Stammler, Theorie der Rechtswissenschaft, 1923, p. 447. Mais recentemente, Friedrich Müller, Die Einheit der Verfassung, 1979, Dunker \& Humblot, p. 199; E.-W. Böckenförde, Grundrechte als Grundsatznormen, em Staat, Verfassung, Demokratie, Suhrkamp, 1991, p. 159-199; Habermas, Faktizität und Geltung, p. 294-324; e Luhmann, Das Recht der Gesellschaft, p. 397-400. O que talvez faça do caso brasileiro um exemplo pitoresco é o aparente recurso ao "método da ponderação" em decisões judiciais sobre os mais variados assuntos e nas mais diversas instâncias, vale dizer, sua nāo-limitação aos "casos dificeis" envolvendo restriçōes a direitos e liberdades fundamentais no âmbito da jurisdição constitucional.
} 
requerida para a fundamentação dogmática da decisão buscada. A malandragem, assim concebida, é um tipo de estratégia que recorre à ordem para promover a desordem e apresentar a desordem como proposta de nova ordem. É quando o direito positivo, tal como interpretado e aplicado, não oferece caminho para a justificação de uma determinada decisão judicial, que entra em cena o consequencialismo malandro, abrindo passagem para a decisão pretendida por intermédio da construção de conceitos e distinçōes que conduzam à referida decisão e a façam aparecer como desde sempre juridicamente admissível e adequada ao caso concreto. Rigorosamente falando, portanto, as construçōes do consequencialismo malandro são sempre juridicamente inválidas ex ante; a sua legitimação se obtém apenas ex post, se e somente se elas são bem-sucedidas, i. e., se persuadem as pessoas que deveriam persuadir para que a solução do caso seja a desejada. Neste sentido pode-se dizer, da malandragem de sucesso, que é legalização silenciosa de um estado de excȩ̧ão.

A malandragem possui importantes atributos positivos. Em primeiro lugar, ela é, de longe, a mais sofisticada das formas de consequencialismo jurídico, pois requer um amplo conhecimento de teoria do direito e de dogmática jurídica e as suas chances de sucesso são uma função crescente desse conhecimento e da capacidade de apresentar a desordem como se ordem fosse. Em segundo lugar, ela pode ser vista como um dos mais importantes canais de produção de inovações no direito, certamente mais importante que a cópia de doutrinas estrangeiras, dado que se orienta na solução de problemas jurídicos específicos e concretos, sendo artesanalmente talhada para esta finalidade. A solução customizada para o problema específico e concreto faz-se, no consequencialismo malandro, usualmente acompanhar, não obstante, e em terceiro lugar, por uma pretensão de generalidade que reflete as exigências da isonomia ou justiça formal. Esta é uma característica essencial a separar a malandragem do oportunismo: das táticas e artimanhas com que se movimentam pelo direito o privilégio, o clientelismo e a corrupçāo. $\mathrm{Na}$ malandragem, cada nova criação passa pela reordenação intelectual de todos os elementos necessários para possibilitar encaixes sem maiores atritos, incluindo a interpretação de normas gerais e precedentes direta e indiretamente aplicáveis, e a compreensão do sentido de antigas categorias dogmáticas. Esse é um esforço não trivial e possivelmente gerador de externalidades positivas significativas para a decisão dos futuros casos. Em suma, o consequencialismo malandro cria, redesenha e eventualmente aperfeiçoa a dogmática jurídica para colocar a seus serviços, ainda que pontualmente e para o caso, um ordenamento jurídico recalcitrante. Trata-se, em quarto e último lugar, de uma qualidade valiosa sobretudo ante regras amplamente percebidas como inadequadas, por exemplo, que produzam, em série, decisões tidas por injustas ou contrárias a valores progressistas. Neste quesito, o malandro compete com largas vantagens sobre o militante. De saída porque, onde este confronta, o primeiro acomoda; e depois, porque a malandragem destrói criativamente, com a eventual geração de subprodutos que promovam direitos e 
liberdades individuais, ao passo que a militância, ao não deixar pedra sobre pedra pelo bem da causa, sabota a própria função protetora do direito e dos juízes.

A existência de uma relação interna entre consequencialismo malandro e dogmática explica por que a malandragem talvez devesse merecer mais simpatia que o pragmatismo jurídico (considerados enquanto estratégias para a justificação de decisōes não conformes às regras prima facie aplicáveis). Nos dois casos, as novas sacadas e as soluçōes inovadoras devem agregar-se ao estoque prévio de doutrinas e decisões de maneira a produzir o menor distúrbio possível. ${ }^{28}$ Como apontado na parte final da Seção 2, entretanto, a deferência aos entendimentos e precedentes vindos do passado está, no pragmatismo jurídico, a serviço da e condicionada pela concepção particular do decisor sobre a contribuição dessa deferência ao bem comum. O pressuposto da malandragem, por sua vez, é que, no direito, o governo do presente deve caber ao passado e não ao futuro. Ao invés de ser concessão do decisor, a deferência agora é uma condicionante do processo de fundamentação da decisão. Assim é que, na inovação malandra, não há celebração de descontinuidades e fissuras heroicamente produzidas, mas, ao contrário, preocupaçāo em religar, sem alardes, a conexão com a ordem que se desfez. Ao menos desta perspectiva, a malandragem é superior a uma atitude teórica que, se importada, difundida e aclimatada em solo nacional, pode bem servir à legitimação do capricho no trato com textos normativos e não normativos em processos de interpretação e aplicação do direito.

De outro lado, a malandragem, como os outros tipos de consequencialismo jurídico, receberá o sinal que lhe conferirem as circunstâncias que cercarem o seu uso, o qual poderá ser conforme ou não a fins capazes de redimi-lo. A malandragem existe para o bem e para o mal, e os riscos associados à mesma não são desprezíveis. O resultado final de um ato de malandragem bem-sucedido, como já mencionado, é a legalização de um estado de exceção à ordem estabelecida. É verdade que isto tudo se realiza dentro da ordem, com a criação dos meios para que a reconfiguração da ordem incorpore elementos que anteriormente lhe eram estranhos. Mas a diferença entre exceção e privilégio é às vezes bastante sutil, nem sempre ficando claro quando estamos diante deste ou daquela. O risco é agravado se levarmos em conta que o processo de destruição criativa que a malandragem desencadeia só avançará na direção do revigoramento da dogmática jurídica se o entorno for propício a essa espécie de avanço. Sob condiçōes de esgarçamento do tecido da dogmática jurídica - como parece ser o caso, atualmente, em diversas áreas do direito no Brasil -, as inovaçōes produzidas para o caso concreto perdem a capacidade de difusão e generalização, desaparecendo sem exercer qualquer impacto estrutural. Se isso de fato ocorre, o beneficiário da malandragem será um privilegiado, que conquista para si uma posição vantajosa sem abrir a terceiros nas mesmas condições, via princípio da isonomia, uma porta (um precedente) passível de reutilização. O mesmo efeito pode obter-se com redefinições particularistas

28 Cf. R. Posner, Legal Pragmatism, Metaphilosophy, 35, 2004, p. 147-159. 
do valor que deveria orientar a hierarquização das consequências associadas à decisão e às suas alternativas. Quanto mais tal valor se aproxima daquilo que é o melhor no curto prazo para uma das partes do litígio (e. g., a melhor decisão definida como aquela que mais atende a seus interesses financeiros), menores serão o grau de incerteza do juízo, a probabilidade de explicitação do argumento que o suporta e o seu potencial generalizador ou de beneficiamento de outros em situação análoga. No limite, o consequencialismo malandro converge para o oportunismo e facilita a corrupção, criando, fortalecendo e consolidando, com a força e as pompas do direito, novos e antigos privilégios individuais.

Não se deve jamais olvidar que os tipos de consequencialismo aqui considerados se caracterizam pela rejeição de decisões resultantes da aplicação de regras de direito positivo, usualmente, de leis ordinárias. Isso por si só já seria suficiente para colocá-los sob suspeita. Quando, em cima disso, se adicionam as razōes epistemológicas anteriormente assinaladas para a deslegitimação de um universo bastante representativo de críticas consequencialistas a decisōes judiciais orientadas em consequências, têm-se motivos para exigir a restrição, a hipóteses excepcionalíssimas, do recurso a quaisquer das três estratégias consequencialistas de justificação de decisōes. Precisamente em virtude do caráter problemático das críticas, é que se recomendam extremos autocontrole e parcimônia no manuseio do objeto contra o qual elas são dirigidas. É certo que as normas que os juízes são chamados a aplicar, em especial as constitucionais, contêm determinaçōes cujo cumprimento somente será factível mediante os esforços coordenados dos três poderes, e que há situações nas quais a impaciência com a aparente falta de iniciativa atinge niveis insuportáveis. Mas, diante delas, existem os canais institucionais adequados, notadamente o voto, os compromissos políticos e as mobilizações populares. Úteis enquanto armas na luta por liberdades individuais nos regimes autoritários, militância e malandragem têm pouco espaço nos estados democráticos de direito. Nestes, alérgicos como são a quem se opõe à legalidade, deve-se resistir à sua utilização inclusive e justamente ali onde ela é mais tentadora: nos nichos em que normas de papel coabitem com a oficialização e a rotinização de desvios e abusos de poder. Quanto ao malandro pra valer, ele de tudo isso sempre soube. 